publicly stated this and added his opinion that no sanitary authority could possibly object to water from streets and roofs of houses, uncontaminated by sewage, being passed directly into any river, Mr. Baldwin Latham might have been expected to have investigated the subject further before adducing the one statement without the other.

There are many other arguments of a sanitary and economical nature in favour of the collection of sewage without more dilution than necessary with rain water, but I must not trespass further on your valuable space.

Alfred S. Jones

\section{Rayons du Crépuscule}

Mx father tells me that he sees this phenomenon about five times in the year on the average in this climate. But the display at 4.40 this afternoon was unusually brilliant. The morning had been very.wet, and when it cleared in W.N.W. at 2.30 we noticed the clear sky to be of an unusually green tint.

Very distant cirro-stratus on the south horizon ceased to be illumined by the rosy sunlight about twelve minutes before the phenomenon became visible. The latter consisted of very bright rosy rays, in a very clear sky, conyerging near the E.N.E. horizun, the moon shining very brightly on the left of the place of apparent convergence. The sky in interspaces between these rays was of a deep blue; these interspaces being, I suppose, the shadows thrown from distant cumuli and shower-clouds, some of which could be seen upon the western horizon.

Ashby Parva, Lutterworth, November ro

ANNIE LEY

The Power of Stupefying Spiders Possessed by Wasps

WiTH reference to my letter on this subject (NATURE, vol. xviii. p. 695), Mr. Arthur Nicols writes me his disbelief that the pretended taking of the poison of snakes internally as a supposed antidote or prophylactic against the bite is anything more than a jurgle of those chartered charlatans, the snake-charmers of India; or that it can be so taken with impunity. Of the wasps he says: "I dare say you know that one of the mason wasps of Australia glues its egg to the inside wall of the mud nest, and always at the top, while the rest of the space is filled with spiders. The sting of this wasp is a terrible affair. I was rendered quite comatose for several hours by being stung in the knee" [which, by the way, is precisely the condition of the spiders], "and the pain was most excruciating, with aching and swelling of the inguinal and axillary glands. I don't know whether the wasp stings the spiders, but they are always in a good state of preservation, even when the egg is on the point of latching. I never found one in the least decomposed. The nest, however, is hermetically sealed, and decomposition could hardly take place, because so very small a quantity of oxygen is inclosed within." It will be remembered that Mr. Armit remarked "a constant movement in the legs of the spiders," and that observation has been made before.

If the word "wasps" in the above heading (which is not mine) be understood to refer to any of the true vespæe (vulgaris, rufa, britannica, or borealis), I aoree with $\mathrm{Mr}$. Frederick Smith (NATURE, vol. xix. p. $3^{2}$ ), that it is misleading. But the solitary insects whose habits have been referred to, have been called wasps in all the popular books of natural history with which I am acquainted; and the correctness, or incorrectness, of the English name does not affect the points brought forward. I may, perbaps, be allowed to recall that the one object for which I referred to the Athenian insect-in connection' with a correspondence then going on in your. columns as to the senses of insects - was the remarkable circumstance that it seems to hunt down its prey by scent. Mr. Armit, of Queensland, referring to that letter, asks the further question, How are the spiders stupefied, and not killed, by a sting, formidable enough in one species to endanger the life of a man? "Mr. Smith's letter throws no light on either of these points.

Bregner Bournemoath

HENRY CECIL

\section{The Ayrshire Crannog}

THE remarks made by Dr. Buchanan White in your last issue in regard to the supposed existence of beech and the absence of Scotch-fir in the Ayrshire Crannog will be carefully attended to. Birch and hazel, so easily recognised by the bark, are certainly in greater abundance than any other kind of wood.
I shall, however, collect as many specimens as I can find and submit them to the examination of competent authorities and publish the result in due course. We have now made a large addition to our list of relics, among which I may mention the following :- -three daggers (one of which has a gold band round the handle); one knife, one gouge-all these are made of metal, of which the gouge alone has been tested and found to be bronze; a polished stone celt; a clay spindle whorl partially perforated; a curious fringe-like object made of vegetable material; several implements of bone and deers'-horn; a piece of wood with carving on it; portions of a flat dish cut out of wood; a wooden scraper cut out of a trunk of a tree with the handle formed of a branch growing straight out from it-(beside this scrape about a handful of short black hair was found); - a double paddle of a canoe together with various other wooden implements. Hitherto not a single fragment of any kind of pottery has been found on the Crannog. Being merely an amateur in this kind of research, I shall be glad to receive any suggestions from experienced gentlemen as to important points that should be looked after.

Kilmarnock, November I6

\section{ON THE UTILISATION OF THE AFRICAN ELEPHANT}

THE Colonies and India, of November 2, contains I a short but suggestive article under the heading "Notes," "Elephants in Cape Colony," which deserves consideration. It states that elephants are numerous in the interior of Cape Colony as well as in Central Africa, yet no one seems to have attempted to catch and tame them. The subject has already been mooted that there is a good field for their use both in Central Africa and in Cape Colony, and that they would prove a new and important method of opening up and utilising the wealth of the Colony and of furthering the explorations in Central Africa, which are now of such general interest.

It appears that a troop of wild elephants has been observed within fifty miles of Port Elizabeth-on these the attempt might first be made--and it is well known that they abound in Central Africa, where, indiscriminately slaughtered for the sake of their ivory, the destruction of these animals is so great, as at no very distant period to threaten their extinction. It seems worthy of consideration whether it would not be better to attempt to utilise them as beasts of burden, as is done in India, where they are of inestimable service to the Commissariat, the Public Works Department, the planters, and many others. The African differs from the Asiatic elepbant in some points, but is equally well adapted for labour, and, there can be no doubt, would be as easily tamed and trained as his Indian congener. That this is the case is amply proved by the docile and submissive state into which the male and female African elephants now in the Regent's Park Gardens have been brought by $\mathrm{Mr}$. Bartlett and their keeper, Scott. They appear to be just as obedient, intelligent, and free from vice as Indian elephants, and there is, I think, little doubt that the one species, under proper training and discipline, would be as useful in Africa as the other is in India.

There is every reason now to hope that the wealth and resources of our South African possessions will undergo development-might it not be well to revive the suggestion that the elephant should be enlisted in the good work? The importation of one or more of the numerous officers who have been trained to the work of catching and domesticating wild elephants in India with a fitting establishment, and, perhaps, a few Indian elephants to commence the work, would very soon put the value of the undertaking to the test, and probably show that a vast source of working power now unused might be made available.

It is probable that in ancient times the African elephant was domesticated, and any one who has studied the two magnificent specimens in the Society's collection in 